\title{
Influence of Product Leadership on the Management of Efficiency Levels in the Pharmaceutical Industry in Kenya
}

\author{
*Antony Muse, Dr. Agnes W. Njeru, Dr. Esther Waiganjo \\ Jomo Kenyatta University of Agriculture and Technology, Nairobi, Kenya
}

\begin{abstract}
This article assessed the influence of Product leadership on the management of efficiency levels in the pharmaceutical industry in Kenya. In research methodology, the study adopted cross sectional survey design. The population of interest was composed of registered Kenyan pharmaceutical manufacturing companies as availed by the KAM directory. Sampling technique was purposively sampling. The research instrument was a questionnaire. Analysis of the data was done using (SPSS). Regression and correlation analysis was done to test the relationship between the study variables. The study findings indicated that there was a positive and significant relationship between product leadership and the management of efficiency levels. The study concluded Kenyan pharmaceutical industry have put a lot effort in producing high quality generic pharmaceutical products but are trying to implement strategic management practices. The study recommends that Kenyan Pharmaceutical companies need to implement product leadership in order to manage its efficiency levels.
\end{abstract}

Keywords: Product leadership, efficiency, Pharmaceutical companies in Kenya.

\section{INTRODUCTION}

Globalization and rapid technological advancement have immensely transformed the way companies do business worldwide, spurred innovation and development in various sectors, and driven the world economic changes (Kotler, 2001). Pharmaceutical companies face complex issues that grow more challenging by the day. Healthcare reform and changes in technology, government policy, and consumer expectations are revolutionizing relationships with key stakeholders and impacting operations in unforeseen ways. Globalization is presenting its own set of challenges that span multiple levels of most pharmaceutical organizations-from marketing to regulatory. Add to the mix the "patent cliff," a sagging economy, shrinking R\&D budgets and lackluster sales pipelines and you have a recipe that would challenge even the most seasoned leadership team. Most experts believe that companies who succeed in the face of such challenges will do so by placing a renewed emphasis on innovation. Moreover, they will adapt effectively in the face of change and uncertainty and will position themselves as a vital partner in the healthcare delivery chain.

\subsection{Statement of the Problem}

Pharmaceutical companies face complex issues that grow more challenging by the day. The United Nations Industrial Development Organization (UNIDO) has embarked on a project to strengthen local manufacturing capacities in the production of a range of essential generic drugs in selected developing and Least Developed Countries (LDCs), with funding from Germany's Federal Ministry for Economic Cooperation and Development (BMZ). Kenya, which has a strong base from which to develop its pharmaceutical industry, decided to collaborate with UNIDO in an effort to further develop this sector. The project aims at the expansion and upgrading of small and medium size enterprises (SMEs) for the local manufacture of essential generic drugs (with a particular emphasis on those combating the three major pandemics: HIV/AIDS, malaria and tuberculosis) with the aim of improving access for the poor to these drugs at affordable prices. It is against the backdrop of disease burdens for countries like Kenya that the African Union Commission (AUC) resolved to develop a Pharmaceutical Manufacturing Plan for Africa within the framework of the New Partnership for Africa's Development (NEPAD), under the theme "to pursue, with the support of our partners, the local production of generic medicines on the continent, and to make full use of the flexibilities within the Trade and Related Aspects of Intellectual Property Rights (TRIPS) and the Doha Declaration on 
TRIPS and Public Health. The bulk of locally manufactured preparations are non-sterile, over thecounter (OTC) products. The number of companies engaged in manufacturing and distribution of pharmaceutical products in Kenya continue to expand, driven by the Government's efforts to promote local and foreign investment in the sector (Were, Sharif, \& Samuel, 2008).

Yet doubts are often expressed as to the viability of pharmaceutical production in developing Countries such as Kenya, mainly with regard to: Small national markets, making it difficult for local manufacturers to achieve economies of scale in production, little value addition in local production, Reliance on government support or protection (Hasan and Wanyanga, 2010).Kenya vision 2030 has projected that pharmaceutical manufacturing as one of the possible areas of investment. This will include: Setting up of pharmaceutical manufacturing industries which can produce drugs, ARVs, and Vaccines (Macro Planning Directorate, 2008).

There are a number of constraints that hamper growth and development of the local pharmaceutical industry. High cost of production resulting from high cost of energy and labor. Kenya has prohibitive energy costs that make it difficult to compete with multinationals, majority of who carry out production in Asian countries (UNIDO, 2010). In addition to the high costs of production inputs, the government levies $16 \%$ value added tax on pharmaceutical raw materials, which makes production costlier. Purchasing of active raw materials is inhibited by low order quantities as the volume of raw materials requested by local industry is too small to justify shipment and wide fluctuations in cost per unit (Wamae \& Kungu, 2014) Other factors that hinder the local pharmaceutical industry from being competitive: plants are relatively old with high maintenance costs and poor efficiency; there is little emphasis on achieving large production runs and machine utilization rates are low; planned maintenance is given low priority and there is little availability of spare parts. Much of the equipment has not been replaced or maintained (UNIDO, 2010). From the foregoing, it is clear, however, that investments in local medicine production will be efficient only if pharmaceuticals can be produced more cheaply locally than they can be imported on the open market. To respond to these needs various strategies have been practiced such as Porters generic strategies, various continuous improvement strategies such as ISO 9000, Total Quality Management, Kaizen, Enterprise Resource Planning, Business and Process Reengineering have been developed. A new paradigm in this area of strategic improvement is operational excellence.

In view of the above review the following study was investigated:

\section{RESEARCH OBJECTIVE}

To determine the influence of Product leadership on the management of efficiency levels in the pharmaceutical industry in Kenya.

\subsection{Hypothesis}

H1: There is a positive significant influence of Product leadership on management of efficiency levels in the pharmaceutical industry in Kenya.

\subsection{Theoretical Framework}

The Ansoff Product-Market Growth Matrix is a marketing tool created by Igor Ansoff and first published in his article "Strategies for Diversification" in the Harvard Business Review (Ansoff, 1957). The matrix allows marketers to consider ways to grow the business via existing and/or new products, in existing and/or new markets - there are four possible product/market combinations. This matrix helps companies decide what course of action should be taken given current performance. The matrix consists of four strategies.

Market penetration; in market penetration strategy, the organization tries to grow using its existing offerings (products and services) in existing markets. In other words, it tries to increase its market share in current market scenario. This involves increasing market share within existing market segments. This can be achieved by selling more products or services to established customers or by finding new customers within existing markets. Here, the company seeks increased sales for its present products in its present markets through more aggressive promotion and distribution. This can be accomplished by: Price reduction, increase in promotion and distribution support, acquisition of a rival in the same market and modest product refinements. While in market development strategy, a firm try to expand into new markets (geographies, countries etc.) using its existing offerings. This can be accomplished by: different customer segments, industrial buyers for a good that was previously 
sold only to the households' new areas or regions of the country and foreign markets. This strategy is more likely to be successful where: -the firm has a unique product technology it can leverage in the new market, it benefits from economies of scale if it increases output, the new market is not too different from the one it has experience of and the buyers in the market are intrinsically profitable.

In product development strategy, a company tries to create new products and services targeted at its existing markets to achieve growth. This involves extending the product range available to the firm's existing markets. These products may be obtained by: investment in research and development of additional products, acquisition of rights to produce someone else's product, buying in the product and "branding" it and joint development with ownership of another product who need access to the firm's distribution channels or brands.

In diversification an organization tries to grow their market share by introducing new offerings in new markets. It is the most risky strategy because both product and market development is required. This can be achieved through concentric diversification, and vertical integration. In unrelated diversification, also termed conglomerate growth because the resulting corporation is a conglomerate, i.e. a collection of businesses without any relationship to one another. A strategy for company growth through starting up or acquiring businesses outside the company's current products and markets (Ansoff, 1957). The theory was applicable in this study because the researcher had theorized that within the framework of the Ansoff growth matrix and the variable product leadership, the matrix allows marketers to consider ways to grow the business via existing and/or new products. In market penetration the pharmaceutical industry could consider selling more established products into existing markets by increased promotion or price reductions or better routes to market, while in product development it will involve pharmaceutical industries developing new products and placing them into existing markets. This involves extending the product range available to the firm's existing markets. These products may be obtained by investment in research and development of additional products thus achieve efficiency in the pharmaceutical industry (Bennett, 1994)

\subsection{Conceptual Framework}

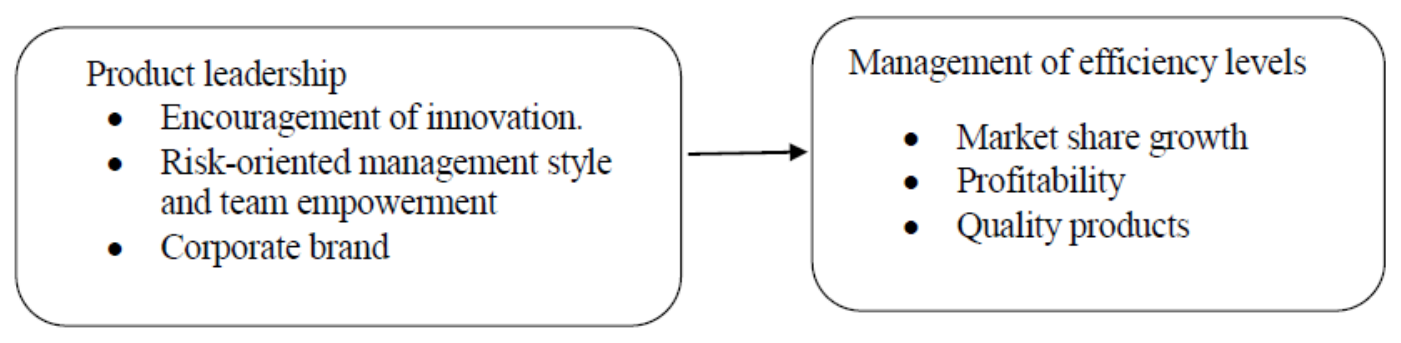

\section{REVIEW OF LITERATURE ON VARIABLES}

\subsection{Product Leadership}

This relates to the differentiation strategies that the firm may implement. The firm develops a competitive advantage by being at the forefront of product or service innovation. To be a product leader, companies face three challenges. First, they must be creative and open-minded to new ideas and opportunities that usually originate outside the company. Second, they must be quick in commercializing their ideas. This asks for the company to be organized like a small, entrepreneurial company. And third, they must relentlessly pursue new solutions to the problems that their own latest product or service has just solved. Product leaders are their own fiercest competitors. To achieve PL, a firm has to be very strong in innovation and branding. The company operates in dynamic markets. The focus is on product development, innovation, design, time to market, and high margins in a short time frame. The corporate disciplines they cultivate include; Research portfolio management, teamwork, product management, and marketing and talent management (Rasmussen, 2003)

Product innovation is broadly seen as an essential component of competitiveness, embedded in the organizational structure, processes, products, operations, and services within a firm. Product innovation is one of the fundamental instruments of growth strategies to enter new markets, to increase the existing market share and to provide the company with a competitive edge (Ibidunni, Iyiola and Ibidunni, 2014) Product leaders recognize that excellence in creativity, problem solving and teamwork is critical to their success. This reliance on expensive talent means that product leaders 
seek to leverage their expertise across geographical and organizational boundaries by mastering such disciplines as collaboration and knowledge management. Reaching that goal requires them to challenge themselves in three ways. First, they must be creative. Being creative means recognizing and embracing ideas that usually originate outside the company. Second, such innovative companies must commercialize their ideas quickly. To do so, all their business and management processes have to be engineered for speed. Third and most important, product leaders must relentlessly pursue new solutions to the problems that their own latest product or service has just solved. Product leaders do not stop for self-congratulation; they are too busy raising the bar. Enterprises must aim at the growing target market, and continue to create products of value given. Product leading companies must make innovative activities and the connotations of the enterprise innovation culture and portfolios of competitiveness in line (Maffin, 1998). The ways to lead the products include:

The significance of product Leadership can be seen in growth in any organization which depends upon customers purchasing from the company, and then making the decision to return time and again. A comprehensive product line, filled with high-quality, value-driven options, is the key to building an engaged customer base. To achieve and maintain product excellence, an organization must strive to be best-in-class in three key areas: understanding demand, nurturing the brand, and differentiating from the competition (Frost and Sullivan., 2014). The first to enter the market- Enterprises, which value positioning on Product Leadership, are always high-tech enterprises. Compared with the traditional industries, as a result of new and existing technologies drive the market in different directions, the life cycle of high-tech industry's product and technology has become shorter, market is rapidly changing. The product-leading company should quickly enter the market and develop appropriate pricing strategy to obtain return on their investment in a possible long time. With the rapid reduction of the product price along the product life cycle, all follow-up will inevitably carry out price competition (Maffin, 1998).

The first to enter the market can get the following advantages; Taking advantage of the market share, taking a strong initial position in the market, to improve the credibility of the leader, Gaining experience earlier than the opponent. The first companies to enter the market can achieve original experiences in areas such as customers, technology, suppliers, distribution channels, etc., so as to form their own supply and marketing network in order to grasp the major distributors and customers and impacting on industry standards. Once the customers have a first impression of a product, then the product will increasingly become the standards of this type of competitive products, other competitors will be hard to change those standards. These standards become barriers to competitors entering the market, but also reach the purpose of extending the product life cycle (Maffin, 1998).

\subsection{Management of Efficiency Levels}

Efficiency as "the quality of doing something well with no waste of time or money". In the context of a production environment, efficiency means the ability to produce a product using the fewest resources possible. Efficient production is achieved when a product is created at its lowest average total cost. Where a business has efficient production, it is operating at maximum output and at minimum cost per unit of output. Efficiency is, therefore, a measure of how well the production or transformation process is performing. However, this is not always easy to assess. There are several ways to measure efficiency (Guesmi, 2013).

Productivity- This measures the relationship between inputs into the production process and the resultant outputs. The most commonly used measure is labor productivity, which is measured by output per worker. High values of both efficiency and effectiveness lead to high productivity and therefore increased competitiveness. Defining productivity as relation between output and input efficiency is furthermore linked to the utilization of resources and mainly concerns the input of the productivity quota while, on the other hand, effectiveness is rather output-focused and relates to satisfying customer demand, linked to the output of the productivity quota. For example, assume a pharmaceutical manufacturer makes 100 batches of product a month and employs 25 workers. The labor productivity is 4 batches per person per month. There are several other measures of productivity; Output per hour / day / week, Output per machine, Unit costs (total costs divided by total output). The unit cost measure is particularly important. A falling ratio would indicate that efficiency is improving. Achieving high production efficiency is important because; A more efficient business will produce lower cost goods than competitors. That means the business can either make a higher profit per unit sold (assuming that the product is sold for the same price as a competitor) or the 
business can offer customers a lower price than competitors (and still make a good profit). Secondly, investing in production assets (e.g. equipment, factory buildings) is expensive, therefore a business needs to maximize the return it makes on these assets (Lieder, 2014).

There are various ways in which a business can try to improve its productivity- Training - e.g. on-thejob training that allows an employee to improve skills required to work more productively, Improved motivation - more motivated employees tend to produce greater output for the same effort than demotivated ones, More or better capital equipment (this links with the topic of automation), better quality raw materials (reduces amount of time wasted on rejected products) and Improved organization of production - e.g. less wastage (Lieder, 2014)

Stock levels-A business will have set itself a target stock level of finished goods that it should achieve. This is calculated to satisfy the demand expected by the marketing department plans and based on what the production department thinks they can produce. If the stock level falls below this level then the productive efficiency has reduced since the output per worker has not met the planned requirements (Guesmi, 2013). Non-productive ("idle") resources- Which resources are not in constant use in the business? Are employees often left with nothing to do? Are machines only used for part of available time? Too many idle resources are a common sign of inefficiency in production.

Cost- For manufacturing, the most significant line item on an income statement is the cost of producing goods for sale (i.e., cost of goods sold or cost of sales). It is a figure which reflects the cost of raw materials used to produce a product to sell to customers. Lieder, (2014) suggest that COGS are the direct costs of producing a product for sale. It could be; Cost of items purchased for resale, cost of raw materials used to produce a product, or cost of parts used to construct a product. COGS also includes direct costs such as labor to produce the product, supplies used in manufacture or sale, shipping costs, costs of containers, freight in, and overhead costs directly related to the manufacture or production activity like rent and utilities for the manufacturing facility.

In summary-efficiency is an important measure of a company's performance. It requires the minimization of inputs and the maximization of profits for a given level of output. Efficiency, therefore, enables a business to make the best possible use of the company's resources. For example, an efficient company will produce a greater number of quality products, with less waste, using less energy and other resources during a given period than an inefficient company. Increasing efficiency will also boost the capacity of a business, assuming there is no change in the number of inputs employed. The capacity of a firm refers to how much a business can produce during a specific period of time.

\section{MeThodology}

This study adopted a cross-section survey design. According to Olsen and Marie, (2004), a crosssection design involves surveying a population for purposes of collecting data from them at a given single point in time. These studies therefore reveal that cross-section designs aim to collect findings on the relationship of variables of interest to the researcher and at a given specific time. The purpose of survey was to produce quantitative descriptions of some aspects of the study population. It sought to seek to confirm hypotheses about phenomena hence use highly structured methods such as questionnaires which are closed-ended and which helped to predict causal relationships between the variables. The choice of survey as a preferred method was because survey analyses are primarily concerned with relationships between variables (Kothari, 2004).

The study only collected findings concerning the problem at a single point because the aim was not to show the trend of changes but rather to identify the responses without manipulating the variables in producing insights into the influence of operational excellence strategy in the management of efficiency levels in the pharmaceutical industry in Kenya taking pharmaceutical companies located in Nairobi and its environs, it was felt that they would best help the researcher in achieving this. Analysis of the data was done using descriptive statistics and inferential statistics using Statistical Package for Social Scientists (SPSS) software in analyzing data. Analysis of the data was done using a combination of designs including descriptive statistics, frequencies and percentages. ), In research methodology, the study adopted cross sectional survey design. The population of interest was composed of all registered Kenyan pharmaceutical manufacturing companies as availed by the KAM directory. The sampling frame was composed of only firms engaged in manufacturing, distribution and marketing of pharmaceutical products in Kenya that formed the researcher's body of interest. 
Sampling technique was purposively sampling. The research instrument was a questionnaire. Analysis of the data was done using descriptive statistics and inferential statistics using Statistical Package for Social Scientists (SPSS) through the use of tools such as chi square test and regression models were fitted and hypothesis testing carried using multiple regression analysis.

\section{RESULTS AND DISCUSSION}

\subsection{Results of Reliability Tests}

Reliability is a measure of the degree to which a research instrument yields consistent result or data after repeated trials (Mugenda and Mugenda, 2003). Reliability in research is influenced by random error. Reliability was tested using Cronbach's coefficient Alpha. Cronbach's Alpha measures how well a set of items or variables, measure a single uni-dimensional latent construct that is a coefficient of reliability or consistency. Reliability is expressed as a coefficient between 0 and 1.00. The higher the coefficient, the more reliable is the test. A threshold of a Cronbach Alpha of 0.7 and above is acceptable (Cronbach, 1951). Cronbach Alpha was used to test the reliability of the proposed constructs. The findings indicated that, product Leadership had a coefficient of 0.894 .

\begin{tabular}{|l|l|l|}
\hline Independent Variable & Reliability Cronbach's Alpha & Comments \\
\hline Product Leadership & 0.894 & Reliable \\
\hline
\end{tabular}

\subsection{Sampling Adequacy}

To examine whether the data collected was adequate and appropriate for inferential statistical tests such as the factor analysis, regression analysis and other statistical tests, two main tests were performed namely; Kaiser-Meyer-Olkin (KMO) Measure of Sampling Adequacy and Bartlett's Test of Sphericity. For a data set to be regarded as adequate and appropriate for statistical analysis, the value of KMO should be greater than 0.5 (Field, 2000). Findings in Table 1:0 showed that the KMO statistic was 0.708 which was significantly high; that is greater than the critical level of significance of the test which was set at 0.5 (Field, 2000). In addition to the KMO test, the Bartlett's Test of Sphericity was also highly significant (Chi-square $=1395.650$ with 630 degrees of freedom, at $\mathrm{p}<$ 0.05). The results of the KMO and Bartlett's Test are summarized in Table 1:0. These results provided an excellent justification for further statistical analysis to be conducted

Table1:0 KMO and Bartlett's Test

\begin{tabular}{|l|l|}
\hline Indicator & Coefficient \\
\hline Kaiser-Meyer-Olkin Measure of sampling Adequacy & 0.708 \\
\hline Bartlett's Chi- Square & 1395.650 \\
\hline Bartlett's Test of Sphericity df & 630 \\
\hline Bartlett's Sig. & 0.000 \\
\hline
\end{tabular}

\subsection{Operational Excellence and Management of Efficiency Levels}

\subsubsection{Factor Analysis}

Factor analysis was conducted after successful testing of sampling adequacy and reliability using KMO coefficient and cronbach alpha results. Factor analysis was conducted using Principal Components Method (PCM) approach. The extraction of the factors followed the Kaiser Criterion where an eigen value of 1 or more indicates a unique factor. Total Variance analysis indicates that the 5 statements on product leadership variable under product innovation can be factored into 1 factor. The total variance explained by the extracted factor is $60.96 \%$ as shown in table 1:2.

Table1:2 Product Innovation KMO

\begin{tabular}{|l|l|l|l|l|l|}
\hline & & Factor & $\begin{array}{l}\text { Overall } \\
\text { Cronbach's } \\
\text { Product innovation }\end{array}$ & $\begin{array}{l}\text { Corrected } \\
\text { Item-Total } \\
\text { Correlation }\end{array}$ & $\begin{array}{l}\text { Total } \\
\text { variance } \\
\text { explained }\end{array}$ \\
\hline $\begin{array}{l}\text { There are regular new product } \\
\text { development forums in your firm }\end{array}$ & 0.639 & .693 & 0.785 & 0.417 & $60.96 \%$ \\
\hline $\begin{array}{l}\text { Our firm manufacturers } \\
\text { customized products }\end{array}$ & .624 & & 0.818 & 0.944 & \\
\hline $\begin{array}{l}\text { Our products are available } \\
\text { through preferred channels }\end{array}$ & .558 & & 0.73 & \\
\hline $\begin{array}{l}\text { We have a research and } \\
\text { development (R\&D) department }\end{array}$ & & .743 & & 0.752 & \\
\hline $\begin{array}{l}\text { We relentlessly pursue new } \\
\text { solutions }\end{array}$ & & .726 & & & \\
\hline
\end{tabular}


Total Variance analysis indicates that risk Orientation can be factored into 1 factor and had a total variance explained by the extracted factor is $46.30 \%$ as shown in table 1:3 from the 3 statements. All the factors attracted coefficients of more than 0.4 hence all the statements were retained for analysis. A factor loading equal to or greater than 0.4 is considered adequate. This is further supported by Hair, Black, Babin, Anderson \& Tatham, (2006) who assert that a factor loading of 0.4 has good factor stability and deemed to lead to desirable and acceptable solutions.

Table1:3 Risk Orientation KMO

\begin{tabular}{|l|l|l|l|l|l|}
\hline Risk Orientation & KMO & $\begin{array}{l}\text { Factor } \\
\text { loadings }\end{array}$ & $\begin{array}{l}\text { Overall } \\
\text { Cronbach's } \\
\text { Alpha }\end{array}$ & $\begin{array}{l}\text { Corrected } \\
\text { Item-Total } \\
\text { Correlation }\end{array}$ & $\begin{array}{l}\text { Total } \\
\text { variance } \\
\text { explained }\end{array}$ \\
\hline $\begin{array}{l}\text { New product decisions are based on risk } \\
\text { management forums }\end{array}$ & 0.503 & .813 & 0.773 & 0.603 & $46.30 \%$ \\
\hline $\begin{array}{l}\text { Creative thinking is encouraged and } \\
\text { rewarded }\end{array}$ & .510 & & 0.603 & \\
\hline $\begin{array}{l}\text { Rewards are based on an employee's ability } \\
\text { to innovate and to bring innovative product } \\
\text { concepts }\end{array}$ & .685 & & 0.667 & \\
\hline
\end{tabular}

Total Variance analysis indicates that the 3 statements of corporate brand can be factored into 1 factor and had a total variance explained by the extracted factor is $50.41 \%$ as shown in table $1: 4$. All the factors attracted coefficients of more than 0.4 hence all the statements were retained for analysis. A factor loading equal to or greater than 0.4 is considered adequate. This is further supported by Hair, Black, Babin, Anderson \& Tatham, (2006) who assert that a factor loading of 0.4 has good factor stability and deemed to lead to desirable and acceptable solutions.

Table1:4 Corporate Brand KMO

\begin{tabular}{|l|l|l|l|l|l|}
\hline Corporate Brand & KMO & $\begin{array}{l}\text { Factor } \\
\text { loadings }\end{array}$ & $\begin{array}{l}\text { Overall } \\
\text { Cronbach's } \\
\text { Alpha }\end{array}$ & $\begin{array}{l}\text { Corrected } \\
\text { Item-Total } \\
\text { Correlation }\end{array}$ & $\begin{array}{l}\text { Total } \\
\text { variance } \\
\text { explained }\end{array}$ \\
\hline $\begin{array}{l}\text { Our logo is legible in a wide range of sizes, } \\
\text { from a tiny web icon to a large banner at a } \\
\text { trade show. }\end{array}$ & 0.548 & .501 & 0.745 & 0.231 & $50.41 \%$ \\
\hline $\begin{array}{l}\text { The colors used by our company } \\
\text { communicate many different messages and } \\
\text { can sometimes be so iconic that our products } \\
\text { can be recognized solely by a swatch of color }\end{array}$ & & .778 & & 0.745 & \\
\hline $\begin{array}{l}\text { Our company has a specific font that is used } \\
\text { throughout our company's materials }\end{array}$ & & .810 & & 0.917 & \\
\hline
\end{tabular}

Table 1:2, table 1:3 and table 1:4 shows the factor loadings for product leadership statements. All the 5 statements on product leadership variable under product innovation , 3 statements on risk Orientation and the 3 statements and corporate brand factors attracted coefficients of more than 0.4 hence all the statements were retained for analysis. A factor loading equal to or greater than 0.4 is considered adequate. This is further supported by Hair,Black, Babin,Anderson \& Tatham, (2006) who assert that a factor loading of 0.4 has good factor stability and deemed to lead to desirable and acceptable solutions

\subsubsection{Descriptive Results}

\section{Encouragement of Innovation}

The study sought to examine the respondent's level of extent with the variable concerning product leadership. The findings in table 1:5 concerning elements of product innovation indicate that majority of the respondents $(56 \%)$ agreed that there are regular new product development forums in their firm with (Mean 1.59 and Std. Deviation 0.523). 72\% of the respondents agreed that the firm manufacturers customized products with Mean 1.80 Std. deviation 0.487 . Only $23 \%$ of the respondents agreed that they have a research and development (R\&D) department with Mean 1.85 and Std. deviation 0.555 . 
Table1:5 Elements of Product Innovation

\begin{tabular}{|l|l|l|l|l|l|l|l|}
\hline Elements of product innovation. & $\begin{array}{l}\text { Strongly } \\
\text { Agree (\%) }\end{array}$ & Agree (\%) & $\begin{array}{l}\text { Neutral } \\
(\%)\end{array}$ & Disagree (\%) & $\begin{array}{l}\text { Strongly } \\
\text { Disagree } \\
(\%)\end{array}$ & Mean & $\begin{array}{l}\text { Std. } \\
\text { deviation }\end{array}$ \\
\hline $\begin{array}{l}\text { There are regular new product } \\
\text { development forums in your firm. }\end{array}$ & 43 & 56 & 1 & 0 & 0 & 1.59 & .523 \\
\hline $\begin{array}{l}\text { Our firm manufacturers } \\
\text { customized products. }\end{array}$ & 24 & 72 & 4 & 0 & 0 & 1.80 & .487 \\
\hline $\begin{array}{l}\text { Our products are available } \\
\text { through preferred channels }\end{array}$ & 27 & 66 & 7 & 0 & 0 & 1.80 & .545 \\
\hline $\begin{array}{l}\text { We have a research and } \\
\text { development (R\&D) department. }\end{array}$ & 23 & 69 & 7 & 1 & 0 & 1.85 & .555 \\
\hline $\begin{array}{l}\text { We relentlessly pursue new } \\
\text { solutions. }\end{array}$ & 34 & 60 & 4 & 1 & 1 & 1.75 & .645 \\
\hline
\end{tabular}

\section{Risk-oriented Management style and Team Empowerment}

The study sought to examine the respondent's level of extent with the variable concerning product leadership. The findings in table 1:6 concerning elements of risk oriented management style indicate that majority of the respondents $(65 \%)$ agreed that new product decisions are based on risk management forums with (Mean 1.75 and Std. Deviation 0.541). 57\% of the respondents agreed that creative thinking is encouraged and rewarded with Mean 1.60 Std. deviation $0.521 .55 \%$ of the respondents agreed that team work is a way of working with Mean1.66 and Std. deviation 0.577. 60\% of the respondents agreed that there is a great focus on speed, commercializing ideas quickly with Mean 1.66 and Std. deviation 0.536

Table1:6 Risk and team empowerment

\begin{tabular}{|l|l|l|l|l|l|l|l|}
\hline $\begin{array}{l}\text { Risk-oriented management style and team } \\
\text { empowerment. }\end{array}$ & $\begin{array}{l}\text { Strongly } \\
\text { Agree (\%) }\end{array}$ & $\begin{array}{l}\text { Agree } \\
(\%)\end{array}$ & $\begin{array}{l}\text { Neutral } \\
(\%)\end{array}$ & $\begin{array}{l}\text { Disagree } \\
(\%)\end{array}$ & $\begin{array}{l}\text { Strongly } \\
\text { Disagree } \\
(\%)\end{array}$ & $\begin{array}{l}\text { Std. } \\
\text { deviation }\end{array}$ \\
\hline $\begin{array}{l}\text { New product decisions are based on risk } \\
\text { management forums. }\end{array}$ & 30 & 65 & 5 & 0 & 0 & 1.75 & .541 \\
\hline $\begin{array}{l}\text { Creative thinking is encouraged and } \\
\text { rewarded. }\end{array}$ & 41 & 57 & 1 & 0 & 0 & 1.60 & .521 \\
\hline $\begin{array}{l}\text { Rewards are based on an employee's ability } \\
\text { to innovate and to bring innovative product } \\
\text { concepts. }\end{array}$ & 28 & 69 & 4 & 0 & 0 & 1.76 & .508 \\
\hline Team work is a way of working & 40 & 55 & 5 & 0 & 0 & 1.66 & .577 \\
\hline $\begin{array}{l}\text { There is a great focus on speed, } \\
\text { commercializing ideas quickly. }\end{array}$ & 37 & 60 & 3 & 0 & 0 & 1.66 & .536 \\
\hline
\end{tabular}

\section{Corporate Brand}

The study sought to examine the respondent's level of extent with the variable concerning product leadership. The findings in table 1:7 concerning elements of corporate brand indicate that majority of the respondents $(60 \%)$ agreed that there logo is legible in a wide range of sizes, from a tiny web icon to a large banner at a trade show with (Mean 1.64 and Std. Deviation 0.526). 74\% of the respondents agreed that the colors used by their company communicate many different messages and can sometimes be so iconic that there products can be recognized solely by a swatch of color with Mean 1.84 Std. deviation $0.488 .63 \%$ of the respondents agreed that their company has a specific font that is used throughout the company's materials with Mean1.81 and Std. deviation 0.603.

Table1:7 Elements of Corporate Brand

\begin{tabular}{|l|l|l|l|l|l|l|l|}
\hline Elements of corporate brand. & $\begin{array}{l}\text { Strongly } \\
\text { Agree }(\%)\end{array}$ & $\begin{array}{l}\text { Agree } \\
(\%)\end{array}$ & $\begin{array}{l}\text { Neutral } \\
(\%)\end{array}$ & $\begin{array}{l}\text { Disagree } \\
(\%)\end{array}$ & $\begin{array}{l}\text { Strongly } \\
\text { Disagree } \\
(\%)\end{array}$ & Mean & $\begin{array}{l}\text { Std. } \\
\text { deviation }\end{array}$ \\
\hline $\begin{array}{l}\text { Our logo is legible in a wide range } \\
\text { of sizes, from a tiny web icon to a } \\
\text { large banner at a trade show. }\end{array}$ & 38 & 60 & 2 & 0 & 0 & 1.64 & .526 \\
\hline
\end{tabular}




\begin{tabular}{|c|c|c|c|c|c|c|c|}
\hline $\begin{array}{l}\text { The colors used by our company } \\
\text { communicate many different } \\
\text { messages and can sometimes be so } \\
\text { iconic that our products can be } \\
\text { recognized solely by a swatch of } \\
\text { color. }\end{array}$ & 21 & 74 & 5 & 0 & 0 & 1.84 & .488 \\
\hline $\begin{array}{l}\text { Our company has a specific font } \\
\text { that is used throughout our } \\
\text { company's materials. }\end{array}$ & 28 & 63 & 8 & 1 & 0 & 1.81 & .603 \\
\hline $\begin{array}{l}\text { Photos and all imagery have a } \\
\text { consistent look and feel, i.e. The } \\
\text { photos are brightly lit and the } \\
\text { subject is looking right into the } \\
\text { camera. }\end{array}$ & 27 & 63 & 9 & 1 & 0 & 1.84 & .603 \\
\hline $\begin{array}{l}\text { Our firm has a full library of } \\
\text { graphic elements including } \\
\text { background texture, a line style } \\
\text { treatment, and use of white space } \\
\text { or color blocks. }\end{array}$ & 59 & 40 & 1 & 0 & 0 & 1.43 & .526 \\
\hline
\end{tabular}

The objective of the study was to determine the influence of Product leadership on the management of efficiency levels in the pharmaceutical industry in Kenya. From the summary in table 1:5, table 1:6 and table 1:7 indicate that majority (56\%) of the respondents concerning elements of product innovation agreed that there are regular new product development forums in there firm. $72 \%$ of the respondents agreed that their firm manufacturers customized products. Only 23\% of the respondents agreed that they have a research and development $(\mathrm{R} \& \mathrm{D})$ department. The findings in table 1:6 concerning elements of risk oriented management style indicate that majority of the respondents $(65 \%)$ agreed that new product decisions are based on risk management forums. $57 \%$ of the respondents agreed that the creative thinking is encouraged and rewarded. 55\% of the respondents agreed that team work is a way of working. $60 \%$ of the respondents agreed that there is a great focus on speed, commercializing ideas quickly. Corporate brand indicates that majority of the respondents $(60 \%)$ agreed that their logo is legible in a wide range of sizes, from a tiny web icon to a large banner at a trade show. $74 \%$ of the respondents agreed that the colors used by their company communicate many different messages and can sometimes be so iconic that their products can be recognized solely by a swatch of color. 63\% of the respondents agreed that there company has a specific font that is used throughout the company's materials. Cha and Yu, (2014) analyzed 492 drug launches in 131 classes over a 27-year period (1986-2012). Their analysis showed that first-in-class players on average achieve a greater-than-fair market share hence overall, first-to-market players have a 6 percent market-share advantage over later entrants thus product innovation and having an R\& D facilities are important for a company's sustainability.

\subsection{Test of Assumptions of the Study Variables}

When the assumptions of the linear regression model are correct, ordinary least squares (OLS) provides efficient and unbiased estimates of the parameters (Long \& Ervin, 2000). To ensure that there was no violation of the assumptions, this study tested for linearity, homoscedasticity, and multicollinearity. Linearity refers to the consistent slope of change that represents the relationship between an independent variable and a dependent variable. If the relationship between the independent and the dependent variables is radically inconsistent, then structural equation modeling analyses will be difficult to carry out (Mark, 2003). If the significant value for deviation from linearity is less than 0.05 , the relationship between independent and dependent variables is not linear, and this presents problems during modeling. Mark also states that issues of linearity can also be fixed by removing outliers. This shall be shown by the normal Q-Q plot.

\subsection{Outliers and Normality Tests of the Study Variables}

Outliers were tested univariately on the dependent variable because the dependent variable constructs were in continuous scales. Univarate outliers are extreme values for a single variable (Tabachnick and Fidell, 2007). The results did not show outliers. This was further evidenced in the testing of normality, where the cut-off points for skewness and kurtosis are shown to be outside the -1 and +1 range and more than three times the standard deviation (Kline, 2005). 


\subsection{Normality Test}

The normality of data distribution was assessed by examining its skewness and kurtosis (Kline, 2005). A variable with an absolute skew-index value greater than 3.0 is extremely skewed while a kurtosis index greater than 8.0 is an extreme kurtosis (Kline, 2005). Cunningham (2008) stated that an index smaller than an absolute value of 2.0 for skewness and an absolute value of 7.0 is the least violation of the assumption of normality. The results of the normality test of the dependent variable indicated skewness and kurtosis in the range of -1 and +1 as shown in table 4:37. This implies that the assumption of normality was satisfied. The results presented in Table 4:37 shows that market promotion had a skewness coefficient of -0.168 and its kurtosis coefficient being -0.295 . Based on these it was concluded that data was normally distributed since they lie with the \pm 1 range recommended by Myoung (2008)

Table1:8 Product Leadership Normality Test

\begin{tabular}{|l|l|l|}
\hline Product Leadership & Statistic & Std. Error \\
\hline Mean & 1.7873 & .02624 \\
\hline Median & 1.8041 & \\
\hline Std. Deviation & .30380 & \\
\hline Skewness & -.010 & .209 \\
\hline Kurtosis & -.075 & .416 \\
\hline
\end{tabular}

To corroborate the skewness and kurtosis results, the graphical analysis results showed the line representing the actual data distribution closely follow the diagonal in the normal Q-Q plot as shown in figure 1:1, suggesting normal distribution (Hair, Tatham, Anderson \& Black, 2006). In Q-Q plot, or the normal probability plot, the observed value for each score is plotted against the expected value from the normal distribution, where, a sensibly straight line suggests a normal distribution. By and large, if the points in a Q-Q plot depart from a straight line, then the assumed distribution is called into question (Aas \& Haff, 2006).

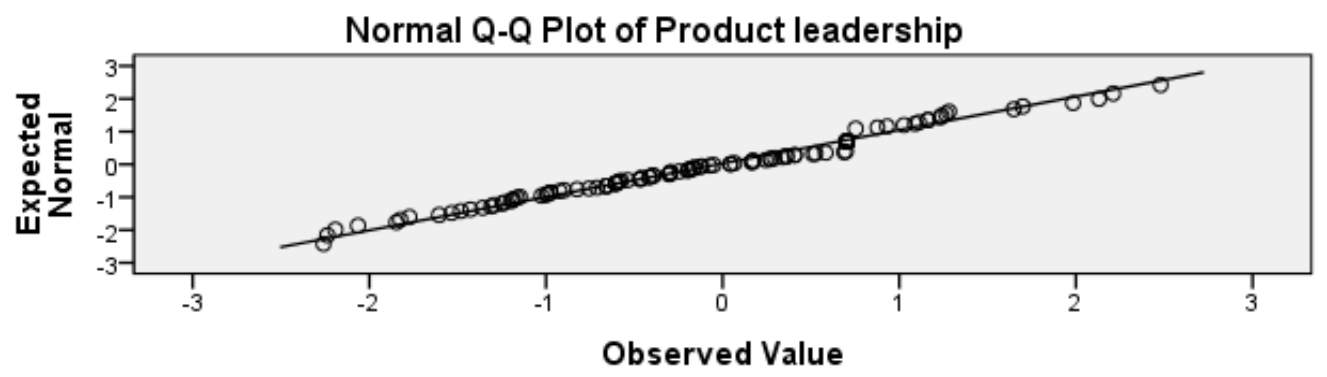

Fig1:1 Q-Q Plot for Product leadership

The dependent variable should be normally distributed because the study was using a multiple linear regression model, where the condition of normality must be satisfied. Figure 1:1 shows the normal QQ plot which indicates that the condition of normality for product leadership is satisfied. According to Shenoy and Madan (1994), for a variable to be normally distributed most of the points should lie on the theoretical Quantile line. The theoretical Quantile line of the data is fitted and from the Normal QQ Plot it indicates that the observed values versus the expected normal values are randomly distributed along the line of best fit indicating that the dependent variable is normally distributed.

\subsection{Relationship between product leadership and the management of efficiency levels}

Table1:9 Product Leadership Correlation

\begin{tabular}{|c|c|c|c|}
\hline \multicolumn{4}{|c|}{ Correlations } \\
\hline & & Management Efficiency & Product leadership \\
\hline \multirow{3}{*}{ Management Efficiency } & Pearson Correlation & 1 & $267^{* * *}$ \\
\hline & Sig. (2-tailed) & & .002 \\
\hline & $\mathrm{N}$ & 134 & 134 \\
\hline \multirow{3}{*}{ Product leadership } & Pearson Correlation & $.267^{* *}$ & 1 \\
\hline & Sig. (2-tailed) & .002 & \\
\hline & $\mathrm{N}$ & 134 & 134 \\
\hline
\end{tabular}

**. Correlation is significant at the 0.01 level (2-tailed). 
Table 1:9 shows the correlation results which indicate that there was a positive and significant relationship between product leadership and management of efficiency levels in the pharmaceutical industry in Kenya. This reveals that any positive change in product leadership led to increased management of efficiency levels in the pharmaceutical industry in Kenya. The relationship has been illustrated by the correlation co-efficient of 0.267 , implying a positive relationship between product leadership and management of efficiency levels in the pharmaceutical industry in Kenya. This was also evidenced by the $\mathrm{p}$ value of 0.002 which is less than that of critical value (0.05).

Regression analysis was conducted to empirically determine whether product leadership was a significant determinant of management of efficiency levels in pharmaceutical industry in Kenya. The coefficient of determination R2and correlation coefficient ( $r$ ) shows that the degree of association between the independent variable and management of efficiency levels. The results of the linear regression indicate $\mathrm{R} 2=0.127$ and $\mathrm{R}=.357$ as shown in table $4: 39$. This is an indication that there is a significant relationship between independent variable product leadership and the dependent management of efficiency levels.

From the model summary table 1:10 adjusted R2 was 0.119 this indicates that product leadership can explain $12.7 \%$ of variations in management of efficiency levels. Therefore, further research should be conducted to investigate these other factors that affect management of efficiency levels in pharmaceutical industry in Kenya

Table1:10 Model Summary Product Leadership

\begin{tabular}{|l|l|l|l|l|}
\hline \multicolumn{5}{|c|}{ Model Summary $^{\mathrm{b}}$} \\
\hline Model & $\mathrm{R}$ & R Square & Adjusted R Square & Std. Error of the Estimate \\
\hline 1 & $.357^{\mathrm{a}}$ & .127 & .119 & .77888 \\
\hline
\end{tabular}

a. Predictors: (Constant), Product leadership

b. Dependent Variable: Management Efficiency

The overall model significance was presented in table 1:11. An F statistic of 15.741 indicated that the overall model was significant as it was less than the critical $F$ value of 15.741 with $(1,109)$ degrees of freedom at the $\mathrm{P}=0.05$ level of significance. The findings imply that product leadership was statistically significant in explaining management of efficiency levels in the pharmaceutical industry in Kenya.

Table1:11 ANOVA Product Leadership

\begin{tabular}{|l|l|l|l|l|l|l|}
\hline \multicolumn{7}{|c|}{ ANOVA $^{\text {a }}$} \\
\hline Model & Sum of Squares & df & Mean Square & F & Sig. \\
\hline \multirow{3}{*}{1} & Regression & 9.549 & 1 & 9.549 & 15.741 & $.000^{\mathrm{b}}$ \\
\cline { 2 - 9 } & Residual & 65.518 & 108 & .607 & & \\
\cline { 2 - 8 } & Total & 75.067 & 109 & & & \\
\hline
\end{tabular}

a. Dependent Variable: Management Efficiency

b. Predictors: (Constant), Product Leadership

Table1:12 Coefficients Product Leader

\begin{tabular}{|c|c|c|c|c|c|c|}
\hline \multirow{3}{*}{\multicolumn{2}{|c|}{$\begin{array}{l}\text { Coefficients }^{\mathrm{a}} \\
\text { Model }\end{array}$}} & \multirow{2}{*}{\multicolumn{2}{|c|}{ Unstandardized Coefficients }} & \multirow{3}{*}{$\begin{array}{l}\text { Standardized Coefficients } \\
\text { Beta }\end{array}$} & \multirow{3}{*}{\multicolumn{2}{|c|}{ Sig. }} \\
\hline & & & & & & \\
\hline & & $\mathrm{B}$ & Std. Error & & & \\
\hline & (Constant) & .579 & .139 & & 4.165 & .000 \\
\hline & Product leadership & .520 & .131 & .357 & 3.967 & .000 \\
\hline
\end{tabular}

a. Dependent Variable: Management Efficiency

The Product leadership coefficients are presented in table 1:12. The results show that there is a positive significant influence of Product leadership on management of efficiency levels in the pharmaceutical industry in Kenya as the regression Coefficient of Product leadership is .520 which is positive and significant ( $\mathrm{p}$ value is 0.000 which is less than 0.05 ) hence the study fails to reject the hypothesis and concludes that there is a positive significant influence of Product leadership on management of efficiency levels in the pharmaceutical industry in Kenya. The fitted equation is as shown below.

$\mathrm{Y}=$ Management Efficiency; X3= Product leadership

$\mathrm{Y}=.579+.520 \mathrm{X} 3$ Product leadership 
These findings are in line with Petrova, (2014) who found out that Continuous innovation is one of the pharmaceutical industry's most defining characteristics. Drug innovation as a business process requires savvy strategic, organizational, and managerial decisions. Behnke, Retterath, Sangster \& Singh, (2014) assert that in a changing industry, survival increasingly depends on leading in categories and distinctive business capabilities as winning companies all focused on building leadership in categories and capabilities as shown by leading value creators, including Roche in oncology and Novo Nordisk in diabetes care, generated at least $50 \%$ of their revenues

from one therapeutic area or primary care. In two cases-Biogen Idec in neurology and Celgene in oncology - more than $90 \%$ of revenues came from a single therapeutic area.

\subsection{Management of Efficiency Levels}

This section presents the results for the dependent variable which is management of efficiency levels in the pharmaceutical industry in Kenya

\subsubsection{Factor Analysis}

Factor analysis was conducted after successful testing of sampling adequacy and reliability using KMO coefficient and cronbach alpha results. Factor analysis was conducted using Principal Components Method (PCM) approach. The extraction of the factors followed the Kaiser Criterion where an eigen value of 1 or more indicates a unique factor. Total Variance analysis indicates that the 2 statements on management of efficiency levels can be factored into 1 factor. The total variance explained by the extracted factor is $60.96 \%$ as shown in table $1: 13$

Table1:13 Product Quality KMO

\begin{tabular}{|l|l|l|l|l|l|}
\hline \multicolumn{1}{|c|}{ Product Quality. } & KMO & $\begin{array}{c}\text { Factor } \\
\text { loadings }\end{array}$ & $\begin{array}{c}\text { Overall } \\
\text { Cronbach's } \\
\text { Alpha }\end{array}$ & $\begin{array}{c}\text { Corrected } \\
\text { Item-Total } \\
\text { Correlation }\end{array}$ & $\begin{array}{c}\text { Total } \\
\text { variance } \\
\text { explained }\end{array}$ \\
\hline $\begin{array}{l}\text { Quality Management has a critical role in } \\
\text { the success of the business }\end{array}$ & 0.5 & .781 & 0.785 & 0.775 & $60.96 \%$ \\
\hline $\begin{array}{l}\text { There are defined specification limits for } \\
\text { Critical to Quality Product Attributes }\end{array}$ & .781 & & 0.775 & \\
\hline
\end{tabular}

Table 1:13 shows the factor loadings for management of efficiency levels. All the two factors attracted coefficients of more than 0.4 hence all the statements were retained for analysis. A factor loading equal to or greater than 0.4 is considered adequate. This is further supported by Hair,Black, Babin,Anderson \& Tatham, (2006) who asserts that a factor loading of 0.4 has good factor stability and deemed to lead to desirable and acceptable solutions

\subsubsection{Descriptive Analysis}

The study sought to examine the respondent's level of extent with the dependent variable management of efficiency levels. The summary of the findings in table 1:14 indicate that majority of the respondents $(60 \%)$ agreed that profit within expectations. This is in line with the report by Simonetti, Clark and Wamae, (2016) who opinioned that Kenya's pharmaceutical production grew continuously from 2007 to 2013. In that period total production of tablets, capsules, liquid preparations for oral use and creams/ointments alone increased from US\$34.1 million to US\$154 million

Table1:14 Profitability for Four Years

\begin{tabular}{|l|l|l|}
\hline Overall level of profitability for the last four years & Frequency & Percent \\
\hline profit above expectation & 2 & 1 \\
\hline profit within expectations & 80 & 60 \\
\hline profit below expectations & 6 & 4 \\
\hline Break even within expectations & 45 & 34 \\
\hline Loss making bearable & 1 & 1 \\
\hline Total & 134 & 100 \\
\hline
\end{tabular}

\subsubsection{Normality Test}

The normality of data distribution was assessed by examining its skewness and kurtosis (Kline, 2005). A variable with an absolute skew-index value greater than 3.0 is extremely skewed while a kurtosis 
index greater than 8.0 is an extreme kurtosis (Kline, 2005). Cunningham (2008) stated that an index smaller than an absolute value of 2.0 for skewness and an absolute value of 7.0 is the least violation of the assumption of normality. The results of the normality test of the dependent variable indicated skewness and kurtosis in the range of -1 and +1 as shown in table 1:15. This implies that the assumption of normality was satisfied. The results presented in table 1:15 shows that management of efficiency levels had a skewness coefficient of -0.642 and its kurtosis coefficient being -0.331 . Based on these it was concluded that data was normally distributed since they lie with the \pm 1 range recommended by Myoung (2008).

Table1:15 Normality of Management of Efficiency Levels

\begin{tabular}{|l|l|l|}
\hline Management of efficiency levels & Statistic & Std. Error \\
\hline Mean & 3.8528 & .09964 \\
\hline Median & 3.5587 & \\
\hline Std. Deviation & 1.15343 & \\
\hline Skewness & .642 & .209 \\
\hline Kurtosis & -.331 & .416 \\
\hline
\end{tabular}

To corroborate the skewness and kurtosis results, the graphical analysis results showed the line representing the actual data distribution closely follow the diagonal in the normal Q-Q plot as shown in figure 1:15, suggesting normal distribution (Hair, Tatham, Anderson \& Black, 2006). In Q-Q plot, or the normal probability plot, the observed value for each score is plotted against the expected value from the normal distribution, where, a sensibly straight line suggests a normal distribution. By and large, if the points in a Q-Q plot depart from a straight line, then the assumed distribution is called into question (Aas \& Haff, 2006).

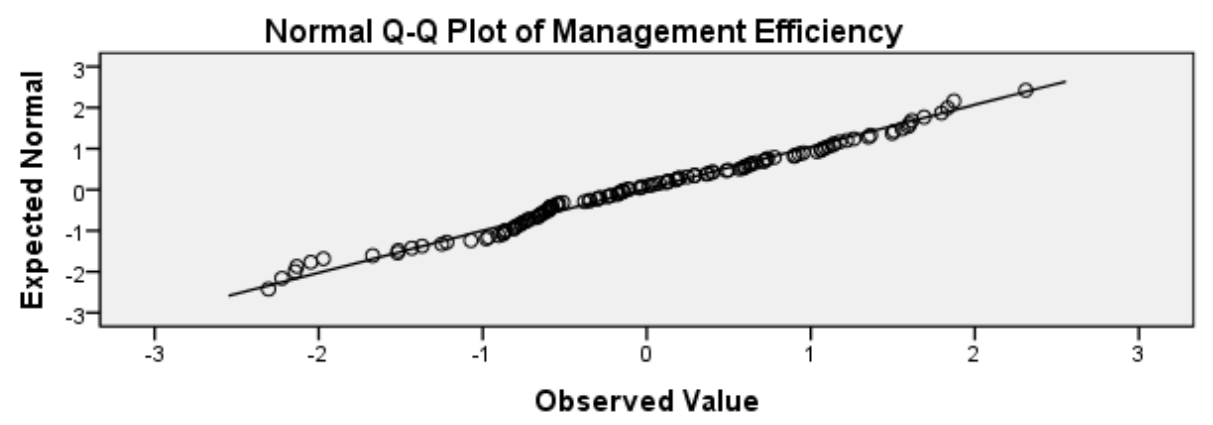

Fig1:2 Q-Q Plot Management of Efficiency

The dependent variable should be normally distributed because the study was using a multiple linear regression model, where the condition of normality must be satisfied. According to Shenoy and Madan (1994), for a variable to be normally distributed most of the points should lie on the theoretical Quantile line. The theoretical Quantile line of the data is fitted and from the Normal Q-Q Plot it indicates that the observed values versus the expected normal values are randomly distributed along the line of best fit indicating that the dependent variable is normally distributed.

\subsubsection{Multicollinearity Test}

Multicollinearity is the undesirable situation where the correlations among the independent variables are strong. In other words, multicollinearity misleadingly bloats the standard errors. Thus, it makes some variables statistically insignificant while they should be else significant. Tolerance of a respective independent variable is calculated from $1-\mathrm{R} 2$. A tolerance with a value close to 1 means there is little multicollinearity, whereas a value close to 0 suggests that multicollinearity may be a threat (Belsley, Kuh, and Welsch, 1980). The reciprocal of the tolerance is known as Variance Inflation Factor (VIF). Equally, the VIF measures multicollinearity in the model in such a way that if no two independent variables are correlated, then all the VIF values will be 1 , that is, there is no multicollinearity among factors. But if VIF value for one of the variables is around or greater than 5, then there is multicollinearity associated with that variable. Table 1:16 indicates the test results for multicollinearity, using both the VIF and tolerance. With VIF values being less than 5, it was concluded that there was no presence of multicollinearity in this study. The VIF shows us how much the variance of the coefficient estimate is being inflated by multicollinearity. 
Antony Muse et al.

Table1:16 Multicollinearity Test

\begin{tabular}{|l|l|l|}
\hline \multirow{2}{*}{ Variables } & Collinearity Statistics \\
\cline { 2 - 3 } & Tolerance & VIF \\
\hline Product Leadership & .626 & 1.598 \\
\hline
\end{tabular}

\subsubsection{Test of Product Leadership Hypothesis}

The hypothesis states that there is a significant positive influence of Product leadership on management of efficiency levels in the pharmaceutical industry in Kenya.

To test the hypothesis linear multiple regression is done which gives outputs given in table 1:17, table $1: 18$ and table $1: 19$. The value of $\mathrm{R}=0.357$ which shows that the relationship between Product leadership and management of efficiency levels in the pharmaceutical industry in Kenya is strong and positive. Coefficient of determination is 0.127 which implies that $12.7 \%$ changes in management of efficiency can be explained by variation in Product leadership.

Table1:17 Product Excellence Hypothesis

\begin{tabular}{|l|l|l|l|l|}
\hline \multicolumn{5}{|c|}{ Model Summary $^{\mathrm{b}}$} \\
\hline Model & $\mathrm{R}$ & R Square & Adjusted R Square & Std. Error of the Estimate \\
\hline 1 & $.357^{\mathrm{a}}$ & .127 & .119 & .77888 \\
\hline
\end{tabular}

a. Predictors: (Constant), Product leadership

b. Dependent Variable: Management Efficiency

The ANOVA table 1:18 shows $F$ value $=15.741$, alpha $(\alpha)=0.01$ and $P$ value $=0.000 . F$ value falls within the rejected region. Since $\alpha$ is $>$ than $\mathrm{P}$ value, and we fail to reject the hypothesis

Table1:18 Product Leadership Hypothesis

\begin{tabular}{|l|l|l|l|l|l|l|}
\hline \multicolumn{9}{|c|}{ ANOVA $^{\text {a }}$} \\
\hline \multirow{2}{*}{ Model } & Sum of Squares & df & Mean Square & F & Sig. \\
\hline \multirow{3}{*}{1} & Regression & 9.549 & 1 & 9.549 & 15.741 & $.000^{\mathrm{b}}$ \\
\cline { 2 - 8 } & Residual & 65.518 & 108 & .607 & & \\
\cline { 2 - 5 } & Total & 75.067 & 109 & & & \\
\hline
\end{tabular}

a. Dependent Variable: Management Efficiency

b. Predictors: (Constant), Product Leadership

Table1:19. Product Leadership Hypothesis

\begin{tabular}{|c|c|c|c|c|c|c|}
\hline \multicolumn{7}{|c|}{ Coefficients $^{\mathrm{a}}$} \\
\hline \multirow{2}{*}{\multicolumn{2}{|c|}{ Model }} & Unsta & Coefficients & Standardized & \multirow[t]{2}{*}{$\mathrm{t}$} & \multirow[t]{2}{*}{ Sig. } \\
\hline & & B & Std. Error & Beta & & \\
\hline \multirow{2}{*}{1} & (Constant) & .579 & .139 & & 4.165 & .000 \\
\hline & Product leadership & .520 & .131 & .357 & 3.967 & .000 \\
\hline
\end{tabular}

a. Dependent Variable: Management Efficiency

There is a positive significant influence of There is a positive significant influence of Product leadership on management of efficiency levels in the pharmaceutical industry in Kenya as the regression Coefficient of Product leadership is .520 which is positive and significant ( $p$ value is 0.000 which is less than 0.05) hence the study fails to reject the hypothesis and concludes that there is a positive significant influence of Product leadership on management of efficiency levels in the pharmaceutical industry in Kenya

\subsection{Discussion of Research Findings}

The study reported a significant positive influence of Product leadership on management of efficiency levels in the pharmaceutical industry in Kenya. The study findings collaborate with brand perceived quality concept and its effectiveness which has received considerable attention and acceptance by both marketing scholars and practitioners such as Hooley, Nicoulaud, Piercy, (2011). Competition in the pharmaceutical industry occurs on the development of new drugs, and the sale of drugs (Aitken, Berndt and Cutler, 2009). Companies compete to be the first in the market with a drug to meet an unmet medical need or with a drug that is safer or more effective at treating a condition or disease 
than current treatments. The first in the market will often gain a substantial first-mover advantage, largely as a result of establishing standard physician prescribing practices. Pharmaceutical companies also compete in marketing of drugs. Several different market participants are involved today in purchasing pharmaceuticals, which may complicate market definition analyses. The competitive environment is dynamic and continually evolving. As soon as one company augments its product to gain a competitive advantage, its competitors seek to nullify the threat by adding a similar attribute to their own product (Mitra, 2006). Companies pursuing product leadership continually push products into the realm of the unknown, the untried, or the highly desirable. Reaching that goal requires that they challenge themselves in three ways. First, they must be creative. More than anything else, being creative means recognizing and embracing ideas that may originate anywhere -- inside the company or out. Second, they must commercialize their ideas quickly. To do so, all their business and management processes are engineered for speed. Third and most important, they must relentlessly pursue ways to leapfrog their own latest product or service. If anyone is going to render their technology obsolete, they prefer to do it themselves. Product leaders do not stop for selfcongratulation. They are too busy raising the bar. Product leaders have a vested interest in protecting the entrepreneurial environment that they have created.To that end, they hire, recruit, and train employees in their own mold. However, the Kenyan pharmaceutical industry research and development is in its infancy (Simonetti,Clark and Wamae, 2016).

\section{CONCLUSION}

The objective of the study was to was to determine the influence of product leadership on the management of efficiency levels in the pharmaceutical industry in Kenya. The study findings indicated that there was a positive and significant relationship between product leadership and the management of efficiency levels. This reveals that any positive change in product leadership led to increased efficiency.

These results are in line with the Ansoff Product-Market Growth Matrix model. The matrix allows marketers to consider ways to grow the business via existing and/or new products, in existing and/or new markets - there are four possible product/market combinations. This matrix helps companies decide what course of action should be taken given current performance. The matrix consists of four strategies;-Market penetration, product development strategy, product diversification and new product development. The model was applicable in this study because the researcher had theorized that within the framework of the Ansoff growth matrix and the variable product leadership, the matrix allows marketers to consider ways to grow the business via existing and/or new products. In market penetration the pharmaceutical industry could consider selling more established products into existing markets by increased promotion or price reductions or better routes to market, while in product development it will involve pharmaceutical industries developing new products and placing them into existing markets. This involves extending the product range available to the firm's existing markets. These products may be obtained by investment in research and development of additional products thus achieve efficiency in the pharmaceutical industry

\section{RECOMMENDATION}

Based on the results, findings and conclusions the following recommendations have been proposed.

The study established that the pharmaceutical firms were adopting various competitive strategies in order to achieve competitive advantage. It is recommended that the firms adopt strategies that would ensure that the production of drugs is maintained at its lowest cost so that they can offer products at the lowest price and achieve competitive advantage over its competitors.

The firms should implement appropriate product leadership strategies and take immediate reaction to the competition. Focus should be on providing value by developing the best product. Pharma companies focusing on this strategy should display an emphasis on creativity and innovation and typically produce a continuous stream of state-of-the-art products. The government should create an enabling environment for businesses to improve their overall competitiveness in the industry. The regulatory issues should encourage instead of hampering business success. This can be done by regular plan-do-check-act feedback loop via the member associations such as KAM. Firms cooperate instead of compete with one another to gain stronger market power and competitive market position. Collaborating with other firms not only alleviates competition and improves their competitive position in the market, but also helps them avoid potential costs resulting from intensified competition. 


\section{ACKNOWLEDGEMENT}

First and foremost, I would like to thank my supervisors Dr. Esther Waiganjo and Dr. Agnes Njeru who taught me and for their support and feedback on my work, for the fruitful collaboration on papers, and for always responding to my questions at any time of day or night.

In particular, I also would like to express my gratitude to my superiors Ahsan Manji and Pritpal Deogun for their strong support and for giving me time to study. I would like to express my sincere gratitude to my mentors Mike Tyler, Clive Ernstzen and Susan Munyiri for always encouraging me to practice Lean Six Sigma. Last but not least, I would like to express my sincere gratitude to my family for the sacrifice made during my study.

\section{REFERENCES}

Aas and Haff, K. (2006). The Generalized Hyperbolic Skew Student's t-Distribution,. Journal of Financial Econometrics, 4(2), 275-309.

Aitken, Berndt and Cutler, M. R. (2009). Prescription drug spending trends in the United States: looking beyond the turning point. Health Affairs, Vol. 28.

Ansoff, I. (1957). Strategies for Diversification,. Harvard Business Review, Vol. 35 Issue 5, 112-113.

Behnke, Retterath, Sangster \& Singh, N. (2014). New paths to value creation in pharma. San Francisco: Bain \& Company.

Bennett, A. R. (1994). Business Planning: Can the Health Service Move from Strategy into Action? Journal of Management in Medicine, Vol. 8, No. 2, 24-33.

Guesmi, B. (2013). The productive efficiency in agriculture: recent methodological advances. Barcelona: Universitat Politècnica de Catalunya.

Hair,Black, Babin,Anderson \& Tatham, J. (2006). Multivariate Data Analysis (6th Edition). Upper Saddle River, NJ: : Prentice-Hall.

Hasan and Wanyanga, S. (2010). Pharmaceutical Sector Profile: Kenya Global UNIDO Project: Strengthening the local production of essential generic drugs in the least developed and developing countries. Nairobi: UNIDO Project.

Hooley ,Nicoulaud ,Piercy, G. (2011). Marketing Strategy and Competitive Positioning . Edinburgh: Prentice Hall.

Ibidunni, Iyiola and Ibidunni, O. (2014). Product Innovation, A survival strategy for small and medium enterprises in Nigeria. European Scientific Journal vol.10, No 1, 194-209.

KAM. (2015, January). 11th Edition Kenya Manufacturers and Exporters Directory 2015. Nairobi: Kenya Association of Manufacturers

Kline, R. B. (2005). Principles and practice of structural equation modeling. New York: The Gilford press.

Kothari , C. (2004). Research Methodology: Methods and Techniques, 2nd edition. New Delhi, India: New age International Publishers.

Kotler, P. (2001). A Framework for Marketing Management. New Delhi: Pearson.

Lieder, M. (2014). Integrated evaluation of resource efficiency and cost effectiveness in production systems. Stockholm: KTH Royal Institute of Technology.

Long and Ervin, S. J. (2000). Using Heteroscedasticity Consistent Standard Errors in the Linear Regression Model. Indiana: Indiana University.

Macro Planning Directorate . (2008). A Summary of key investment opportunities in Kenya. Nairobi: Vision 2030,

Maffin, D. (1998). Engineering design models: Context, theory and practice. Journal of Engineering design, Vol 9, No 4, 315-327.

Mitra, B. (2006). Innovative Intervention in the IP Debate: Rise of the Knowledge Economy. New Delhi: Liberty Institute.

Mugenda \& Mugenda, O. M. (2003). Research Methods Quantitative and qualitative approaches. Nairobi: Acts Press.

Myoung , H. P. (2008). Univariate Analysis and Normality Test Using SAS ,Stata, and SPSS. Indiana: The Trustees of Indiana University. 
Olsen and Marie, D. (2004, February 20). Cross-Sectional Study Design and Data Analysis. Retrieved from http://www.collegeboard.com: http://www. collegeboard.com/ prod_downloads/ yes/ 4297 MODULE_05.pdf

Petrova, E. (2014). Innovation in the Pharmaceutical Industry:The Process of Drug Discovery and Development. New York: Washington State University.

Rasmussen, B. (2003). Aspects of the Pharmaceutical Business Model:Implications for Australia. Melbourne City: Victoria University of Technology.

Simonetti,Clark and Wamae, R. (2016). Pharmaceuticals in Kenya:The Evolution of Technological Capabilities. Nairobi: Creative Commons Attribution.

Shenoy and Madan, G. V. (1994). Statistical methods in business and social sciences. New Delhi: Macmillan.

UNIDO. (2010). Pharmaceutical Sector Profile: Kenya: Global UNIDO Project. Nairobi: United Nations Industrial Development Organization.

Wamae \& Kungu, W. J. (2014). Pharmaceutical manufacturing in Kenya:key trends and developments. Nairobi: African centre for Technology studies.

Were, Sharif, \& Samuel, S. (2008, December). National HealthStrategic Plan for Kenya. Retrieved from Ministry of Public Health and Sanitation: www.publichealth.go.ke/ ministy_of_public_ health_and_sanitation_. National Health Strategic Plan

\section{AUTHORS' BIOGRAPHY}

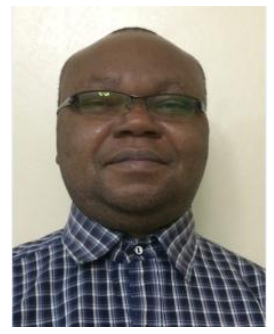

Antony Muse, Student at Jomo Kenyatta University of Agriculture \& Technology, Nairobi, Kenya. Very experienced in FMCG supply chain and well versed in Lean manufacturing philosophy and strategy deployment.

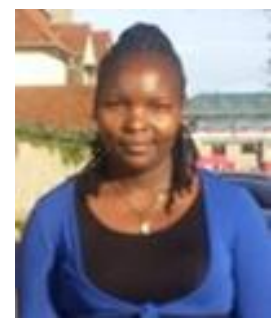

Dr. Agnes W. Njeru, Senior Lecturer Finance and Entrepreneurship, Jomo Kenyatta University of Agriculture \& Technology, Nairobi, Kenya and Coordinator at JKUAT-Karen campus-BBIT \& DBIT Programs .

Dr. Esther Waiganjo, Senior Lecture Jomo Kenyatta University of Agriculture \& Technology, Nairobi, Kenya , College of human resource development, Chairperson of Entrepreneurship, Technology, Leadership and Management Department (ETLM ), School of entrepreneurship, procurement \& management (SEPM ) 